\title{
Work Posture Analysis of Packing Process Workers Using the REBA and OWAS Method (Case Study: Tiga Hati Mutiara, Sukoharjo)
}

\section{Analisis Postur Kerja Pekerja Proses Pengepakan Menggunakan Metode REBA dan OWAS (Studi Kasus : Tiga Hati Mutiara, Sukoharjo)}

\author{
Hafidh Munawir, Isnainiyah Wardatul Jannah, Eko Setiawan \\ \{hafidh.munawir@ums.ac.id\}
}

Program Studi Teknik Industri, Fakultas Teknik, Universitas Muhammadiyah Surakarta

\begin{abstract}
Tiga Hati Mutiara is a food industry located in Sukoharjao, Central Java. One of the activities in the production process is the packaging. The posture of the workers in the packing process is to stand and bend over. The position of the worker is very dangerous if it is done repeatedly and continuously. This study aims to identify the posture and ergonomic risks of workers and provide suggestions for improving worker posture. The methods used in this research are the Rapid Entire Body Assessment (REBA) method and the Ovako Work Posture Analysis System $(O W A S)$ method. The results of the research on the packaging process using the REBA method obtained a score of 8 , which means that the level of risk is high and needs immediate improvement, while the OWAS method has a score of 4, which means that this attitude is very dangerous for the musculoskeletal system and needs immediate improvement. Improvements made are to improve the position of workers and dimensions of the table. After the improvement, the REBA score was 2 and OWAS was 1, which means that the proposed posture condition is good.
\end{abstract}

Keywords - OWAS; REBA; Work Posture

\begin{abstract}
Abstrak. Tiga Hati Mutiara merupakan industri makanan yang berlokasi di Sukoharjao, Jawa tengah. Salah satu kegiatan di dalam proses produksi adalah pengepakan. Postur pekerja pada proses pengepakan adalah dengan berdiri dan membungkuk. Posisi pekerja tersebut sangat berbahaya jika dilakukan secara berulang dan terus menerus. Penelitian ini bertujuan untuk mengidentifikasi postur dan risiko ergonomi pekerja dan memberikan usulan perbaikan postur pekerja. Metode yang digunakan dalam penelitian ini adalah metode Rapid Entire Body Assessment (REBA) dan metode Ovako Work Posture Analysis System (OWAS). Hasil penelitian pada proses pengepakan dengan menggunakan metode REBA diperoleh skor sebesar 8 artinya level risiko tinggi dan perlu segera dilakukan perbaikan, sedangkan metode OWAS diperoleh skor 4 yang artinya pada sikap ini sangat berbahaya bagi sistem muskuloskeletal dan perlu perbaikan secara langsung. Perbaikan yang dilakukan adalah dengan memperbaiki posisi pekerja dan dimensi dari meja. Setelah dilakukan perbaikan diperoleh nilai REBA menjadi 2 dan OWAS menjadi 1 yang artinya kondisi postur yang diusulkan sudah bagus.
\end{abstract}

Kata Kunci-OWAS; REBA; Postur Kerja

\section{Pendahuluan}

Kegiatan proses produksi di suatu industri baik dalam industri dengan skala besar maupun kecil selalu disertai faktor-faktor yang mengandung risiko bahaya yang dapat menyebabkan kecelakaan kerja maupun penyakit akibat kerja [1]. Tenaga kerja yang melakukan proses produksi dengan sikap atau posisi kerja yang tidak nyaman dan berlangsung dalam waktu yang lama bisa menyebabkan pekerja cepat mengalami kelelahan serta membuat banyak kesalahan[2]. Ergonomi adalah ilmu pengetahuan yang mengatur dan mendalami hubungan antara manusia (psycology dan physiology), mesin/peralatan, lingkungan kerja, organisasi dan tata cara kerja untuk dapat menyelesaikan task dengan tepat, efisien, nyaman dan aman [3]. Ergonomi berkaitan dengan optimasi, efisiensi, kesehatan, keselamatan dan kenyamanan seseorang di tempat kerja, di rumah, dan tempat rekreasi [4]. Penggunaan tenaga manusia dalam dunia industri di Indonesia masih sangat dominan, terutama pada kegiatan Manual Material Handling (MMH). Kegiatan Manual Material Handling (MMH) apabila dilakukan secara tidak ergonomis akan menyebabkan gangguan muskulosceletal. Manual Material Handling (MMH) adalah seni dan ilmu yang mencakup penanganan (handling), pemindahan (moving), pengepakan (packaging), penyimpanan (storing), dan pengawasan (controlling) terhadap material dengan segala bentuknya [5].

Tiga Hati Mutiara merupakan perusahaan yang bergerak di bidang Makanan. Tiga Hati Mutiara memproduksi butiran mutiara yang masih dilakukan dengan manual dengan menggunakan tenaga manusia. Salah satu proses yang menggunakan manusia (manual material handling) adalah pada proses pengepakan di unit pengemasan. Kondisi pekerja hingga saat ini belum dilakukan pengukuran fisiologis. Terdapat beberapa kondisi tubuh yang akan mengakibatkan risiko cidera dalam jangka waktu yang panjang, contohnya pada proses pengepakan pekerja melakukan pengepakan produk yang dilakukan selama 7 jam dengan posisi berdiri terlalu lama yang cenderung 
menopang berat badan dengan satu kaki, posisi badan membungkuk, mengangkat, dan posisi badan memutar menyamping. Postur tubuh atau body alignment adalah susunan geometri dari nagian-bagian tubuh yang berhubungan dengan bagian tubuh yang lain seperti persendian, tendon, ligamen, dan otot [6]. Postur tubuh merupakan titik penentu dalam menganalisis keefektifan dari suatu pekerjaan, apabila postur tubuh dalam bekerja sudah baik dan ergonomis maka dapat dipastikan hasil yang diperoleh oleh pekerja akan baik dan sebaliknya jika postur kerja operator tersebut tidak ergonomis maka pekerja akan kelelahan dan dapat terjadi kelainan pada bentuk tulang [7].

Pada permasalahan khusus yang diteliti adalah gangguan musculoskeletal. Oleh karena itu, dilakukan analisis terhadap postur kerja pada proses pengepakan dengan metode Rapid Entire Body Assesment (REBA) dan Ovako Work Posture Analysis System (OWAS). Gangguan musculoskeletal adalah cidera pada bagian otot rangka dana sistem saraf yang disebebabkan oleh tugas yang berulang, pengerahan tenaga melebihi batas, getaran, kompresi mekanik dengan menekan permukaan keras berlebihan, atau posisi canggung sewaktu bekerja [8]. Faktor-faktor risiko keluhan musculoskeletal adalah aktivitas berulang, sikap kerja tidak alamiah, gerakan otot berlebihan, beban, postur janggal, durasi, getaran, dan suhu [10]. Postur kerja yang bisa menyebabkan bahaya yaitu berlutut, membungkuk, maju dan mundur membungkuk, jongkok, bekerja dengan ketinggian melebihi kepala, memutar, meraih ke belakang, serta pergelangan tangan menekuk [11]. Posisi pekerja yang membungkukan badannya saat berdiri dapat menyebabkan nyeri punggung bawah, sehingga kondisi pekerja seperti itu harus diperbaiki[12].

Rappid Entire Body Assesment (REBA) merupakan alat analisis untuk memberikan pengamatan terhadap postur kerja yang cepat dan mudah, selain itu REBA juga merupakan alat analaisis untuk kegiatan statis dan dinamis serta dapat memberikan tingkat tindakan risiko terhadap keluhan muskuloskeletal [13]. Kelebihan metode REBA yaitu cepat untuk menganalisa postur tubuh yang dapat menyebabkan bahaya ergonomi, bisa mengidentifikasi faktor-faktor bahaya dalam pekerjaan, dapat menganalisa postur tubuh yang stabil dan tidak stabil, hasil penilaiannya dapat digunakan untuk menyelesaikan masalah dan menentukan prioritas perbaikan [14].

Ovako Work Posture Analysis System (OWAS) adalah metode analisa sikap kerja dengan mengidentifikasikan pergerakan bagian tubuh punggung, lengan, kaki dan berat beban yang diangkat [15]. Metode OWAS digunakan untuk mengukur seluruh aktivitas kerja, dibagi beberapa interval waktu dalam menit atau detik, sehingga diperoleh beberapa sampling postur kerja dari suatu siklus kerja[16]. Kelebihan Metode OWAS adalah cepat dalam identifikasi sikap kerja yang dapat menimbulkan kecelakaan kerja, kecelakaan kerja [17]. Tujuan dari metode OWAS adalah identifikasi risiko pekerjaan yang dapat membahayakan tubuh manusia yang bekerja [18].

Tujuan dari penelitian ini adalah mengidentifikasi postur dan risiko ergonomi pekerja pada proses pengepakan, menganalisis postur kerja pekerja pada proses pengepakan dengan metode REBA dan OWAS, dan memberikan usulan perbaikan postur kerja pekerja pada proses pengepakan berdasarkan metode REBA dan OWAS.

\section{METODE}

Penelitian ini dilakukan di Tiga Hati Mutiara yang beralamat di DK. Kendalsari RT 03 RW III Kwarasan, Grogol, Sukoharjo, Jawa Tengah, Indonesia. Data yang digunakan dalam penelitian ini adalah data primer yang berupa data postur tubuh operator proses pengepakan, dan data sekunder yang diperoleh dari berbagai sumber seperti buku, laporan, jurnal, dan lain-lain.

Langkah-langkah penelitian antara lain, (i) Melakukan observasi langsung di unit pengemasan bagian proses pengepakan; (ii) Mengidentifikasi masalah yang ada dalam bagian pengepakan; (iii) Pengambilan data pada bagian pengepakan secara langsung dengan cara mengambil foto postur tubuh pekerja yang sedang melakukan aktivitas; (iv) Pengolahan dan analisis data menggunakan metode REBA dan OWAS. Level risiko pada metode REBA dapat dilihat pada Tabel 1. Sedangkan kategori level sikap kerja pada metode OWAS dapat dilihat pada Tabel 2.

Tabel 1. Level Risiko REBA

\begin{tabular}{cccc}
\hline Level Aksi & Skor REBA & Level Risiko & Tindakan Perbaikan \\
\hline 0 & 1 & Bisa diabaikan & Tidak perlu \\
1 & $2-3$ & Rendah & Mungkin perlu \\
2 & $4-7$ & Sedang & Perlu \\
3 & $8-10$ & Tinggi & Perlu segera \\
4 & $11-15$ & Sangat Tinggi & Perlu saat ini juga \\
\hline
\end{tabular}

(Sumber : [19])

Tabel 2. Kategori Level Sikap Kerja OWAS 
Procedia of Engineering and Life Science Vol. 1. No. 2 Juni 2021

Seminar Nasional \& Call Paper Fakultas Sains dan Teknologi (SENASAINS 2nd)

Universitas Muhammadiyah Sidoarjo

\begin{tabular}{cl}
\hline Kategori & \multicolumn{1}{c}{ Penjelasan } \\
\hline 1 & $\begin{array}{l}\text { Pada sikap ini tidak masalah pada sistem muskuloskeletal. Tidak perlu } \\
\text { perbaikan. } \\
\text { Pada sikap ini sedikit berbahaya pada sistem muskuloskeletal. Perlu perbaikan } \\
\text { dimasa akan datang. }\end{array}$ \\
& $\begin{array}{l}\text { Pada sikap ini berbahaya bagi sistem muskuloskeletal. Perlu perbaikan segera } \\
\text { mungkin. }\end{array}$ \\
& $\begin{array}{l}\text { Pada sikap ini sangat berbahaya bagi sistem muskuloskeletal. Perlu perbaikan } \\
\text { secara langsung/saat ini }\end{array}$ \\
\hline
\end{tabular}

(Sumber : [20])

\section{Hasil dan Pembahasan}

Pengumpulan data postur kerja menggunakan foto pada pekerja pengepakan untuk menentukan sudut-sudut pada postur tubuh sikap kerja yang dilakukan oleh pekerja pengepakan. Berikut ini foto postur kerja saat melakukan aktivitas kerja pengepakan dapat dilihat pada Gambar 1 .

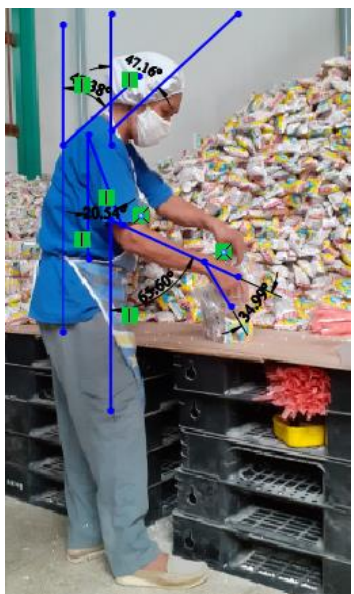

Gambar 1. Foto Postur Kerja Pekerja Pengepakan

\section{A. Analisis menggunakan metode reba}

Uraian untuk Tabel A, yang terdiri atas bagian Punggung, Leher, dan Kaki adalah sebagai berikut :

1. Punggung (Trunk)

Berdasarkan Gambar 1 dapat diketahui bahwa pergerakan punggung termasuk dalam posisi membungkuk dengan sudut $47,38^{\circ}$ dan pergerakan punggung memutar atau miring ke samping. Sehingga skor REBA untuk pergerakan punggung adalah $3+1=4$.

2. Leher $(\mathrm{Neck})$

Berdasarkan Gamber 1 dapat diketahui bahwa pergerakan leher dengan sudut sebesar 47,16 ${ }^{0}$ terhadap sumbu tubuh dan pergerakan leher memutar atau miring kesamping. Sehingga skor REBA untuk pergerakan leher adalah $2+1=3$

3. Kaki (Legs)

Berdasarkan Gambar 1 dapat diketahui bahwa posisi berdiri dengan kaki tidak tertopang bobot tidak tersebar merata/postur tidak stabil. Sehingga skor REBA untuk pergerakan kaki adalah 2.

Adapun Skor REBA untuk Tabel A dapat dilihat pada Tabel 3.

Tabel 3. Tabel Skor REBA Tabel A

\begin{tabular}{|c|c|c|c|c|c|c|c|c|c|c|c|c|c|}
\hline Table & Neck & & & & & & & & & & & & \\
\hline \multirow[t]{3}{*}{ A } & & 1 & & & & 2 & & & & 3 & & & \\
\hline & Legs & 1 & 2 & 3 & 4 & 1 & 2 & 3 & 4 & 1 & 2 & 3 & 4 \\
\hline & 1 & 1 & 2 & 3 & 4 & 1 & 2 & 3 & 4 & 3 & 3 & 5 & 6 \\
\hline
\end{tabular}


Procedia of Engineering and Life Science Vol. 1. No. 2 Juni 2021

Seminar Nasional \& Call Paper Fakultas Sains dan Teknologi (SENASAINS $2^{\text {nd }}$ )

Universitas Muhammadiyah Sidoarjo

\begin{tabular}{llllllllllllll}
\hline \multicolumn{1}{c}{ Trunk } & 2 & 2 & 3 & 4 & 5 & 3 & 4 & 5 & 6 & 4 & 5 & 6 & 7 \\
Posture & 3 & 2 & 4 & 5 & 6 & 4 & 5 & 6 & 7 & 5 & 6 & 7 & 8 \\
Score & 4 & 3 & 5 & 6 & 7 & 5 & 6 & 7 & 8 & 6 & 7 & 8 & 9 \\
& 5 & 4 & 6 & 7 & 8 & 6 & 7 & 8 & 9 & 7 & 8 & 9 & 9 \\
\hline
\end{tabular}

Uraian Tabel B pada Skor REBA terdiri dari lengan atas, lengan bawah, dan pergelangan tangan adalah sebagai berikut :

1. Lengan Atas

Berdasarkan Gambar 1 dapat diketahui bahwa sudut pergerakan lengan atas ke depan sebesar $20,54^{0}$ terhadap sumbu tubuh. Sehingga skor REBA untuk pergerakan lengan atas adalah 2.

2. Lengan Bawah

Berdasarkan Gambar 1 dapat diketahui bahwa sudut pergerakan lengan bawah membentuk sudut $65,60^{\circ}$. Sehingga skor REBA untuk pergerakan lengan bawah adalah 1.

3. Pergelangan Tangan

Berdasarkan Gambar 1 dapat diketahui bahwa sudut pergerakan pergelangan tangan $34,99^{\circ}$ ke bawah. Sehingga skor REBA untuk pergerakan pergelangan tangan adalah 2.

Adapun Skor REBA untuk Tabel B dapat dilihat pada Tabel 4. sedangkan Skor REBA untuk Tabel C dapat dilihat pada Tabel 5.

Tabel 4. Tabel Skor REBA Tabel B

\begin{tabular}{|c|c|c|c|c|c|c|c|}
\hline \multirow{3}{*}{ Table B } & \multicolumn{7}{|c|}{ Lower Arm } \\
\hline & & 1 & & & 2 & & \\
\hline & Wrist & 1 & 2 & 3 & 1 & 2 & 3 \\
\hline \multirow{6}{*}{$\begin{array}{c}\text { Upper } \\
\text { Arm Score }\end{array}$} & 1 & 1 & 2 & 2 & 1 & 2 & 3 \\
\hline & 2 & 1 & 2 & 3 & 2 & 3 & 4 \\
\hline & 3 & 3 & 4 & 5 & 4 & 5 & 5 \\
\hline & 4 & 4 & 5 & 5 & 5 & 6 & 7 \\
\hline & 5 & 6 & 7 & 8 & 7 & 8 & 8 \\
\hline & 6 & 7 & 8 & 8 & 8 & 9 & 9 \\
\hline
\end{tabular}

Tabel 5 Tabel Skor REBA C

\begin{tabular}{|c|c|c|c|c|c|c|c|c|c|c|c|c|}
\hline \multirow{3}{*}{ Score A } & \multicolumn{12}{|c|}{ Table C } \\
\hline & \multicolumn{12}{|c|}{ Score B } \\
\hline & 1 & 2 & 3 & 4 & 5 & 6 & 7 & 8 & 9 & 10 & 11 & 12 \\
\hline 1 & 1 & 1 & 1 & 2 & 3 & 3 & 4 & 5 & 6 & 7 & 7 & 7 \\
\hline 2 & 1 & 2 & 2 & 3 & 4 & 4 & 5 & 6 & 6 & 7 & 7 & 8 \\
\hline 3 & 2 & 3 & 3 & 3 & 4 & 5 & 6 & 7 & 7 & 8 & 8 & 8 \\
\hline 4 & 3 & 4 & 4 & 4 & 5 & 6 & 7 & 8 & 8 & 9 & 9 & 9 \\
\hline 5 & 4 & 4 & 4 & 5 & 6 & 7 & 8 & 8 & 9 & 9 & 9 & 9 \\
\hline 6 & 6 & 6 & 6 & 7 & 8 & 8 & 9 & 9 & 10 & 10 & 10 & 10 \\
\hline 7 & 7 & 7 & 7 & 8 & 9 & 9 & 9 & 10 & 10 & 11 & 11 & 11 \\
\hline 8 & 8 & 8 & 8 & 9 & 10 & 10 & 10 & 10 & 10 & 11 & 11 & 11 \\
\hline 9 & 9 & 9 & 9 & 10 & 10 & 10 & 11 & 11 & 11 & 12 & 12 & 12 \\
\hline 10 & 10 & 10 & 10 & 11 & 11 & 11 & 11 & 12 & 12 & 12 & 12 & 12 \\
\hline 11 & 11 & 11 & 11 & 11 & 12 & 12 & 12 & 12 & 12 & 12 & 12 & 12 \\
\hline 12 & 12 & 12 & 12 & 12 & 12 & 12 & 12 & 12 & 12 & 12 & 12 & 12 \\
\hline
\end{tabular}


Skor berat beban pada proses pengepakan yaitu kurang dari $5 \mathrm{~kg}$, sehingga skor REBA untuk berat beban adalah 0. Skor coupling pada proses pengepakan yaitu pegangan pas dan tidak terlalu kuat, sehingga skor REBA untuk coupling adalah 0 . Proses pengepakan merupakan Aktivitas berulang (lebih dari 4x tiap menit), sehingga Skor REBA untuk aktivitas adalah 1. Berdasarkan Tabel 2.5 diketahui bahwa Score A merupakan hasil dari Skor REBA Tabel A + Skor berat beban. Sedangkan Score B merupakan hasil dari Skor REBA Tabel B + Skor Coupling. Hasil Skor REBA pada proses pengepakan diperoleh Skor C (7) + Skor Aktivitas (1) adalah 8 artinya level risiko tinggi dan perlu segera dilakukan perbaikan.

\section{B. Analisis menggunakan metode owas}

Berdasarkan Gambar 1 dapat ditentukan kode postur kerja dengan menggunakan metode OWAS sebagai berikut :

1. Sikap Punggung. Kode OWAS : 4. Sikap punggung membungkuk ke depan dan menyamping

2. Sikap Lengan. Kode OWAS : 1 . Sikap kedua lengan berada di bawah level ketinggian bahu

3. Sikap Kaki. Kode OWAS : 5. Sikap kaki berdiri dengan beban berada pada salah satu kaki dan salah satu lutut ditekuk

4. Berat Beban. Kode OWAS : 1. Berat beban < 10 kg. Kode Sikap OWAS : 4-1-5-1.

Setelah dilakukan klasifikasi maka dilakukan penilaian analisis postur kerja dengan metode OWAS yang dapat dilihat pada Tabel 6 .

Tabel 6. Penilaian Analisis Postur Kerja OWAS

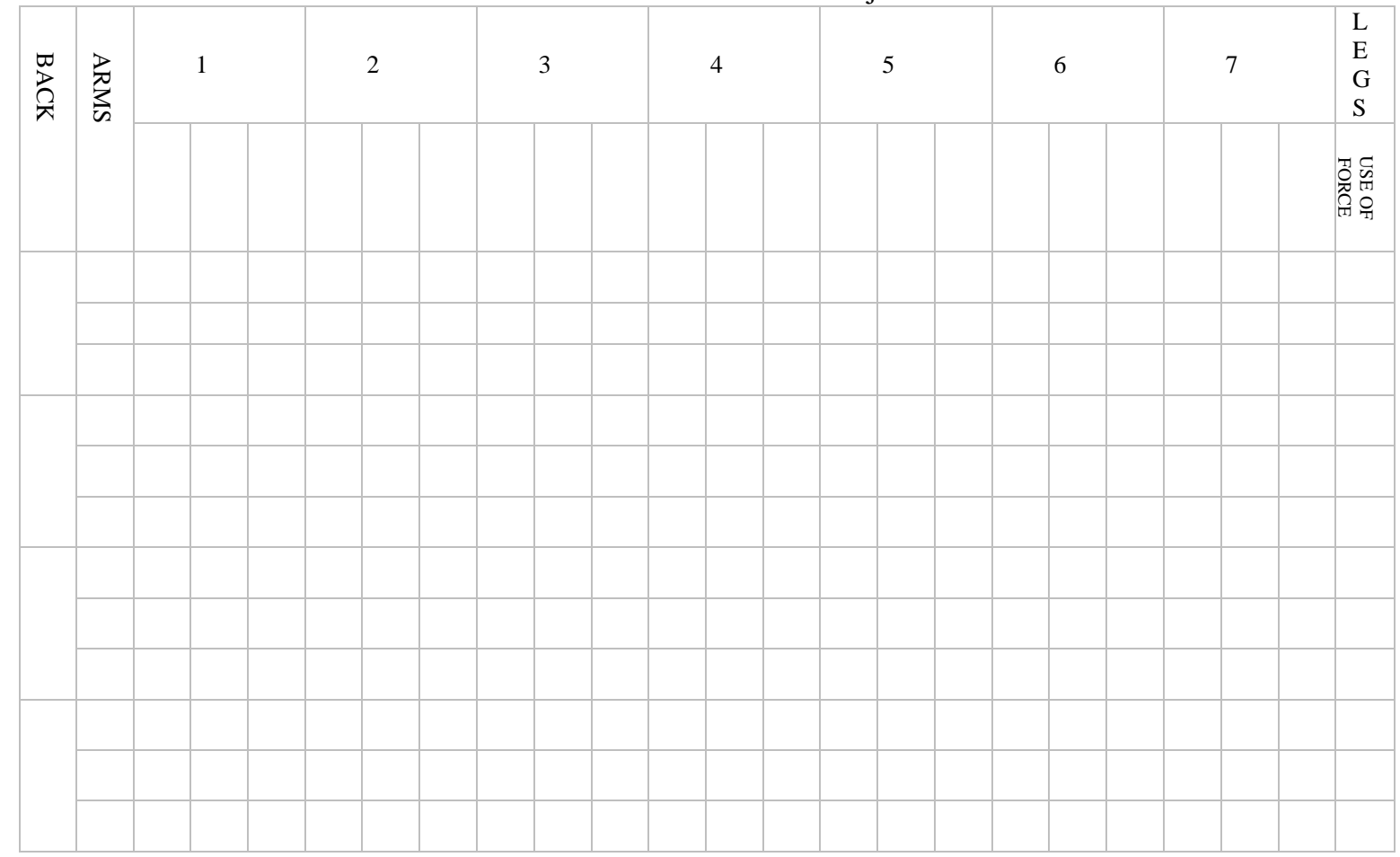

Pada Tabel 6 menunjukkan pengolahan data postur tubuh pada proses pengepakan diperoleh kode OWAS (4-3-51), dengan gabungan sikap tersebut diperoleh nilai tabel OWAS sebesar 4 yang artinya pada sikap ini sangat berbahaya bagi sistem muskuloskeletal dan perlu perbaikan secara langsung/saat ini.

\section{Usulan perbaikan}

Usulan perbaikan yang dapat dilakukan yaitu memperbaiki postur kerja pekerja pengepakan. Usulan perbaikan berdiri dapat dilihat pada Gambar 2. 
Procedia of Engineering and Life Science Vol. 1. No. 2 Juni 2021

Seminar Nasional \& Call Paper Fakultas Sains dan Teknologi (SENASAINS 2nd)

Universitas Muhammadiyah Sidoarjo

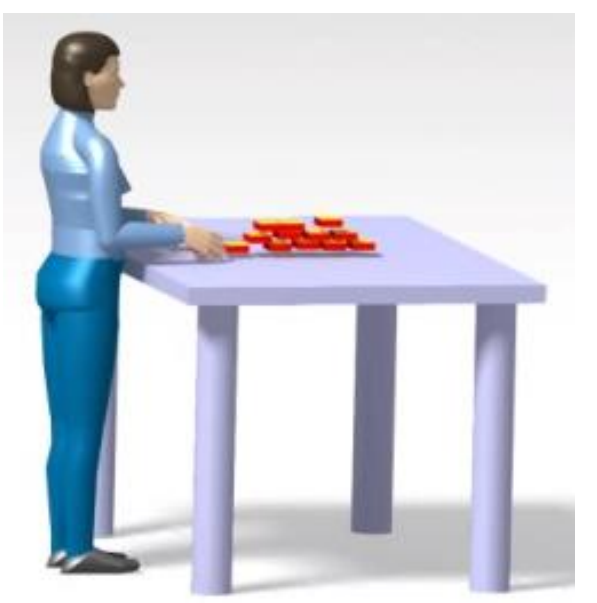

Gambar 2. Usulan Perbaikan Proses Pengepakan

Adapun detail postur kerja proses pengepakan dapat dilihat pada Gambar 3. Sedangkan dimensi usulan perbaikan meja proses pengepakan dapat dilihat pada Gambar 4 .

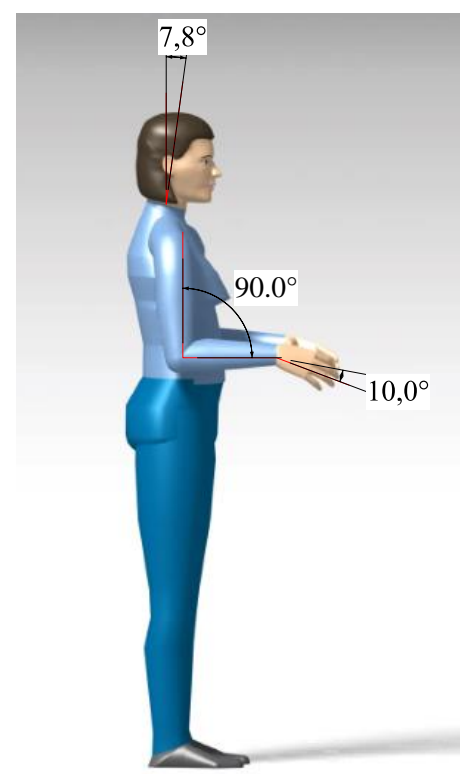

Gambar 3. Usulan Perbaikan Postur Kerja Proses Pengepakan
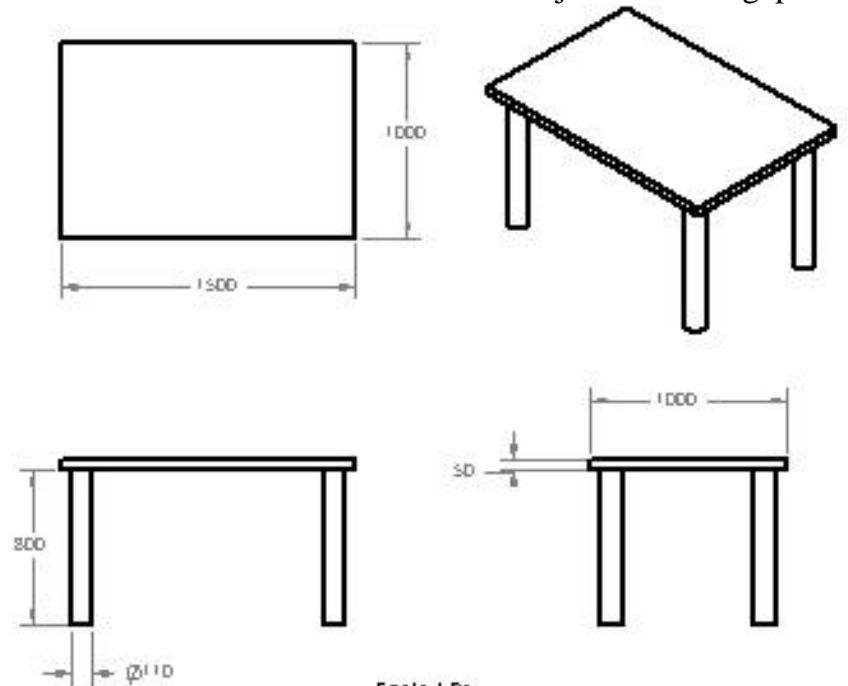

Scole 124 
Gambar 4. Dimensi Meja Usulan Perbaikan Proses Pengepakan

Skor REBA perbandingan kondisi sekarang dan usulan perbaikan dari pekerja proses pengepakan dapat dilihat pada Tabel 7.

Tabel 7. Perbandingan Kondisi Saat Ini dan Usulan Perbaikan

\begin{tabular}{|c|c|c|c|c|c|}
\hline \multicolumn{2}{|c|}{ Kondisi Saat Ini } & & \multicolumn{3}{|c|}{ Usulan Perbaikan } \\
\hline Metode & Skor & Penjelasan & Metode & Skor & Penjelasan \\
\hline & & - Level risiko tinggi & & & -Level risiko rendah \\
\hline REBA & 8 & $\begin{array}{l}\text { - Perlu segera dilakukan } \\
\text { perbaikan }\end{array}$ & REBA & 2 & $\begin{array}{l}\text {-Mungkin perlu } \\
\text { tindakan perbaikan }\end{array}$ \\
\hline OWAS & 4 & $\begin{array}{l}\text { - Sangat berbahaya bagi } \\
\text { sistem muskuloskeletal } \\
\text { - Perlu perbaikan secara } \\
\text { langsung saat ini }\end{array}$ & OWAS & 1 & $\begin{array}{l}\text {-Tidak masalah pada } \\
\text { sistem muskuloskeletal } \\
\text { - Tidak perlu perbaikan }\end{array}$ \\
\hline
\end{tabular}

Berdasarkan Tabel 7 dapat dilihat postur kerja proses pengepakan pada metode REBA mendapat skor 2 yaitu level risiko rendah dan mungkin perlu tindakan perbaikan, sedangkan pada metode OWAS mendapat skor 1 yaitu tidak masalah pada sistem muskuloskeletal dan tidak perlu perbaikan. Pengaplikasian usulan perbaikan postur kerja proses pengepakan menggunakan meja dengan dimensi panjang sebesar $1500 \mathrm{~mm}$, lebar $1000 \mathrm{~mm}$, dan tinggi $850 \mathrm{~mm}$.

\section{KESIMPULAN}

Dalam penilaian postur kerja pekerja proses pengepakan pada unit pengemasan tidak ada perbedaan yang signifikan dalam menilai postur kerja dengan penerapan metode OWAS dan REBA. Penilaian postur tubuh berdasarkan metode REBA memberikan hasil yaitu berlevel risiko tinggi yang perlu segera dilakukan perbaikan, sedangkan berdasarkan metode OWAS memberikan hasil yaitu sangat berbahaya bagi sistem muskuloskeletal dan perlu perbaikan secara langsung. Sehingga penilaian postur tubuh berdasarkan metode REBA dan OWAS memberikan kesimpulan yang sama yaitu level risiko musculoskeletal disorders berada pada tingkat level tinggi, oleh karena itu perlu diperhatikan dengan serius agar mengurangi risiko musculoskeletal disorders. Usulan perbaikan yang dilakukan adalah dengan memperbaiki posisi pekerja dan dimensi dari meja. Setelah dilakukan perbaikan diperoleh nilai REBA menjadi 2 dan OWAS menjadi 1 yang artinya kondisi postur yang diusulkan sudah bagus.

\section{REFERENSI}

[1] S. Musyarofah, A. Setiorini, M. Mushidah, and B. Widjasena, “Analisis Postur Kerja Dengan Metode REBA dan Gambaran Keluhan Subjektif Musculoskeletal Disorders (MSDS) (Pada Pekerja Sentra Industri Tas Kendal Tahun 2017)," Jurnal Kesehatan, no. 1, pp. 24-32, Feb. 2019, doi: 10.23917/jk.v0i1.7669.

[2] S. Wignjosoebroto, Ergonomi, Studi Gerak dan Waktu: Teknik Analisis untuk Peningkatan Produktivitas Kerja. Jakarta: Guna Widya, 1995.

[3] S. Sugiono, W. W. Putro, and S. I. K. Sari, Ergonomi untuk Pemula: (Prinsip Dasar \& Aplikasinya), 1 st ed. Malang: Universitas Brawijaya Press, 2018.

[4] E. Nurmianto, Ergonomi Konsep Dasar dan Aplikasi, 1st ed. Jakarta: Guna Widya, 1998.

[5] S. Wignjosoebroto, Tata Letak Pabrik dan Pemindahan Bahan, 3rd ed. Surabaya: Guna Widya, 2009.

[6] R. Risnanto and U. Insani, Buku Ajar Asuhan Keperawatan Medikal Bedah: Sistem Muskuloskeletal. Yogyakarta: Deepublish, 2014.

[7] W. Susihono and E. Rubiati, "Perbaikan Metode Kerja Berdasar Rapid Upper Limb Assessment (RULA) Pada Perusahaan Konstruksi dan Fabrikasi," Spektrum Industri, vol. 11, no. 1, pp. 107-116, Apr. 2013, doi: 10.12928/si.v11i1.1644.

[8] F. Sulianta, 101+ Pengetahuan Bikin Kamu Mahir IT. Jakarta: Elex Media Komputindo, 2018.

[9] R. Bridger, Introduction to Ergonomics, Third Edition, 3rd edition. Boca Raton: CRC Press, 2008.

[10] T. Tarwaka, Ergonomi Industri; Dasar-Dasar Pengetahuan Ergonomi Dan Aplikasi Di Tempat Kerja, 2 nd ed. Surakarta: Harapan Press , 2014.

[11] R. F. Nur, E. R. Lestari, and S. A. Mustaniroh, "Analisis Postur Kerja pada Stasiun Pemanenan Tebu dengan Metode OWAS dan REBA, Studi Kasus di PG Kebon Agung, Malang," Industria: Jurnal Teknologi dan Manajemen Agroindustri, vol. 5, no. 1, pp. 39-45, Apr. 2016, doi: 10.21776/ub.industria.2016.005.01.5. 
[12] M. Osni, “Gambaran Faktor Risiko Ergonomi dan Keluhan Subjektif Terhadap Gangguan Muskuloskeletal Discorders (MSDs) Pada Penjahit Sektor Informal Di Kawasan Home Industry RW 6 Kelurahan Cipadu Kecamatan Larangan Kota Tanggerang Pada Tahun 2012," Undergraduate Thesis, Universitas Indonesia, 2012.

[13] Q. Qutubuddin, S. S. Hebbal, and A. C. S. Kuma, "Ergonomic Evaluation of Tasks Performed by Workers in Manual Brick Kilns in Karnataka,India," Global Journal of Research in Engineering, vol. 13, no. 4, 2013.

[14] A. Astari, "Gambaran Postur Kerja Petani Rumput Laut dengan Metode REBA di Pulau Kanalo II Kecamatan Pulau Sembilan Kabupaten Sinjai," Undergraduate Thesis, Universitas Islam Negeri Alauddin , Makassar, 2017.

[15] A. R. Pamula, "Analisis Postur Kerja Pada Aktivitas Manual Material Handling Dengan Menggunakan Metode Penilaian Ovako Work Analysisi System (OWAS) Pada Pekerja Unit di PT X Wilayah Semarang," Undergraduate Thesis, Universitas Diponegoro, Semarang, 2012.

[16] Y. Hidjrawan and A. Sobari, "Analisis Postur Kerja Pada Stasiun Sterilizer Dengan Menggunakan Metode OWAS dan REBA,” Jurnal Optimalisasi, vol. 4, no. 1, pp. 1-10, Dec. 2019, doi: 10.35308/jopt.v4i1.1315.

[17] W. Anggraini and A. M. Pratama, "Analisis Postur Kerja dengan Menggunakan Metode Ovako Working Analysis System (Owas) pada Stasiun Pengepakan Bandela Karet (Studi Kasus di PT. Riau Crumb Rubber Factory Pekanbaru)," SITEKIN: Jurnal Sains, Teknologi dan Industri, vol. 10, no. 1, pp. 10-18, Dec. 2012, doi: 10.24014/sitekin.v10i1.570.

[18] G. Santoso, Ergonomi Terapan. Jakarta : Prestasi Pustaka Publisher, 2013.

[19] S. Hignett and L. McAtamney, "Rapid entire body assessment (REBA)," Appl Ergon, vol. 31, no. 2, pp. 201205, Apr. 2000, doi: 10.1016/s0003-6870(99)00039-3.

[20] O. Karhu, R. Härkönen, P. Sorvali, and P. Vepsäläinen, “Observing working postures in industry: Examples of OWAS application,” Appl Ergon, vol. 12, no. 1, pp. 13-17, Mar. 1981, doi: 10.1016/0003-6870(81)90088-0. 